\title{
KEEGSTRA AND ANDREWS: \\ A COMMENTARY ON HATE PROPAGANDA AND THE FREEDOM OF EXPRESSION
}

\author{
BY DINO BOTTOS*
}

The author reviews recent competing Court of Appeal decisions on the wilful promotion of hatred and the freedom of expression. The reconciliation of the competing claims, themselves representing the conflict between group rights and individual rights, is dealt with in the context of recent Supreme Court of Canada jurisprudence.

\section{TABLE OF CONTENTS}

I. INTRODUCTION $\ldots \ldots \ldots \ldots \ldots \ldots \ldots \ldots \ldots \ldots \ldots . \ldots \ldots 1$

II. THE FACTS AND LAW IN KEEGSTRA AND ANDREWS . ... 462

III. THE POLICY BEHIND THE LAW $\ldots \ldots \ldots \ldots \ldots \ldots \ldots \ldots, 463$

IV. ANALYSIS OF SECTION 2(b) $\ldots \ldots \ldots \ldots \ldots \ldots \ldots \ldots \ldots 463$

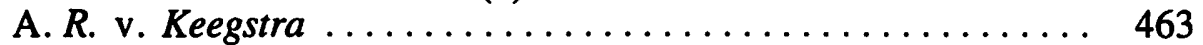

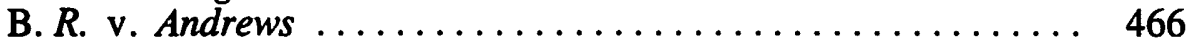

V. ANALYSIS OF SECTION $1 \ldots \ldots \ldots \ldots \ldots \ldots \ldots, 468$

A. $R$. v. Keegstra ............................. 468

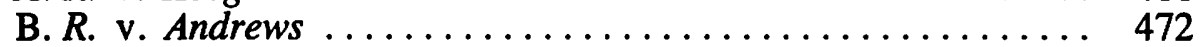

VI. CONCLUSION $\ldots \ldots \ldots \ldots \ldots \ldots \ldots \ldots \ldots \ldots \ldots \ldots, 475$

\section{INTRODUCTION}

The cases of $R$. v. Keegstra ${ }^{1}$ and $R$. v. Andrews ${ }^{2}$ have provided recent judicial commentary on the constitutionality of Canada's anti-hate provision, s.319(2) of the Criminal Code. ${ }^{3}$ Section $319(2)$ and (3) reads:

(2) Everyone who, by communicating statements, other than in private conversation, wilfully promotes hatred against any identifiable group is guilty of

(a) an indictable offence and is liable to imprisonment for two years; or

(b) an offence punishable on summary conviction.

(3) No person shall be convicted of an offence under subsection (2)

(a) if he establishes that the statements communicated were true;

(b) if, in good faith, he expressed or attempted to establish by argument an opinion upon a religious subject;

(c) if the statements were relevant to any subject of public interest, the discussion of which was for the public benefit, and if on reasonable grounds he believed them to be true; or

(d) if, in good faith, he intended to point out, for the purpose of removal, matters producing or tending to produce feelings of hatred towards an identifiable group in Canada.

An "identifiable group" is defined by s.318(4) as " . . . any section of the public distinguished by colour, race, religion or ethnic origin". The Crown may proceed

* Student-at-law with the firm Campney \& Murphy, Vancouver, B.C.

1. (1985) 19 C.C.C. (3d) 254 (Alta. Q.B.), (1988) 60 Alta. L.R. (2d) 1 (Alta. C.A.).

2. R. v. Andrews and Smith (1988), 28 O.A.C. 161 (Ont. C.A.).

3. R.S.C. 1985 , c. C42. Note that all references to section $319(2)$ in quoted passages use numbering of R.S.C. 1970, c. 34 (Section $281.2(2)$ ). 
on an offence under s.319(2) only with the consent of the provincial Attomey General. ${ }^{4}$

Aside from the question of s.319's possible infringement of s.11(d) of the Charter, the focal issue of the two cases is whether we, pursuant to the means chosen in s.319(2) and our ideals of establishing and maintaining a free and democratic society, can justify a limitation on the freedom of expression when the content of that expression is the wilful promotion of hatred against an identifiable group. The Alberta Court of Appeal in Keegstra determined that s.319 unjustifiably infringed s.2(b) of the Charter while the Ontario Court of Appeal in Andrews held that the freedom of expression did not extend to the wilful promotion of hatred.

Within the commentary to follow, the author seeks to examine the analysis of each of the two appellate courts regarding the issue of hate propaganda and the freedom of expression and to evaluate the strengths of these decisions in light of recent Supreme Court of Canada decisions.

\section{THE FACTS AND LAW IN KEEGSTRA AND ANDREWS}

In $R$. v. Keegstra the accused was charged with promoting hatred against an identifiable group (the Jewish people) contrary to s.319(2) of the Criminal Code by communicating statements while teaching at Eckville High School. The indictment cited this criminal action over the course of four years, 1978 to 1982 . Prior to the trial the accused had applied to a Judge in Chambers to quash the indictment on the ground that s.319(2) was an infringement of the accused's freedom of expression under s.2(b) of the Charter. The application was refused. After the trial and conviction of Mr. Keegstra an appeal to the Alberta Court of Appeal was sought on two grounds: first, that s.319(2) and (3) breached the accused's s.11(d) Charter right to be presumed innocent until proven guilty; and second, that s.319(2) breached s.2(b) of the Charter. Furthermore, it was claimed by the accused that these breaches were not saved by $\mathrm{s} .1$ of the Charter and that the criminal statute should be declared of no force or effect by virtue of $s .52$ of the Charter.

In $R$. v. Andrews both accused were charged under the same criminal provision as was Mr. Keegstra. The method of their communication was through publication and distribution of various materials including the Nationalist Reporter, a bi-monthly publication of the Nationalist Party of Canada, a "white nationalist political organization". ${ }^{5}$ The material gathered as evidence was held to be hate propaganda and the accused were ultimately convicted. The constitutional validity of s.319(2) was not called into question at or before trial by the accused. The Ontario Court of Appeal, nevertheless, granted leave to appeal on the issue in light of ss.11(d) and 2(b) of the Charter.

In both the Keegstra and Andrews cases the requirements of mens rea and actus reus were established by the Crown. The only issue remaining for appeal was the criminal section's constitutional validity. 


\section{THE POLICY BEHIND THE LAW}

Section 319(2) of the Criminal Code was given Royal Assent on June 11, 1970. The legislation was the result of recommendations made in the Report of the Special Committee on Hate Propaganda in Canada (also known as the Cohen Committee). ${ }^{6}$ The scope of the Committee's mandate was set out within the Report itself: $^{7}$

The role of the Committee was advisory only. It was invited to study the general question submitted to it by the Minister; to conduct its enquiries informally and briefly; and to submit a report to him surveying the nature and scope of the hate propaganda problem in Canada in all of its various aspects and to consider and prepare recommendations for its suppression and control, if such measures were deemed to be necessary.

Following the gathering of social, psychological and legal information, interviewing various authorities in each of these fields, and examining documents and files presented to it by the Departments of Justice and External Affairs, the Committee submitted its report to the Minister of Justice in 1966. The Cohen Committee made the following conclusions: ${ }^{8}$

1. Notwithstanding the relatively few instances of overt group organizations engaged in the distribution of hate propaganda in Canada, the problem was serious. ${ }^{9}$

2. The legal remedies existing at the time of the report were not sufficient to curb the threat of hate propaganda dissemination in Canada.

3. The best solution in curbing such dissemination was through legislating a law forbidding it. The Committee determined: ${ }^{10}$

The prevailing view in Canada is that freedom of expression is a qualified right, representing the balance that must be struck between the social interest in the full and frank discussion necessary to a free society on the one hand, and the social interests in public order and individual group reputation on the other hand.

4. The drafting of anti-hate legislation should always give preference to freedom of expression over that of legal prohibition but not to the point where the liberty to speak is seen as colouring the quality of the very system of liberty that the freedom of expression is founded upon.

The Cohen Committee adopted as its model the civil tort of defamation and suggested further safeguards to protect the more innocent types of defamation. Throughout five years of Parliamentary debate, the defenses to s.319(2) were expanded into the current form contained in s.319(3).

\section{ANALYSIS OF SECTION 2(b)}

\section{A. $R$. v. KEEGSTRA}

As stated above, the initial application of the accused to strike down s.319(2) was refused. In the holding of Mr. Justice Quigley, the wilful promotion of hatred

6. Report of the Special Committee on Hate Propaganda in Canada, (1966) Queen's Printer and Controller of Stationery, Ottawa, Canada.

7. Id. at 1 .

8. Id. at 61-67.

9. Id. at 59 .

10. Id. at 60 . 
against an identifiable group did not come under the protection of s.2(b) of the Charter. His Lordship decided this on the strength of the preamble to the Canadian Bill of Rights, and ss.15 and 27 of the Charter. With reference to s.27, Justice Quigley stated:"

This section compels an interpreter of the Charter to do so in a particular way. Is it in accord with a requirement to interpret the Charter in a manner consistent with the preservation and enhancement of the multicultural heritage of Canadians to interpret the phrase "freedom of expression" as including the freedom to publicly and wilfully promote hatred against a section of the Canadian public distinguished by colour, race, religion or ethnic origin? In my view, the only rational answer is "No".

The Alberta Court of Appeal took a decidedly different view than that of Justice Quigley. Whereas the Chambers Judge held to the view of finding internal limitations to the Charter guarantees, the Court of Appeal took the approach that limiting factors to a Charter guarantee should only be considered under s.1. Mr. Justice Kerans, speaking for a unanimous Court, explained the method by which an analysis of ss. 1 and 2 of the Charter was to proceed. He stated: ${ }^{12}$

This court, since the decision under appeal, has said that the curtailment of a Charter right in order to give effect to a competing claim, including another Charter right is best considered as part of the office of s. 1 of the Charter, because that provision offers mechanics for the balancing that is inevitable when two valid claims are in conflict: see Edmonton Journal v. Alia. (A.G.) . . . This is not to say that there are no internal limits to the protection offered by s.2(b). Those limits must, however, spring from the nature and purpose of the right itself, and not from competing claims: see Grier v. Alta. Optometric Assn. . . . Insofar as the chamber judge's concem about harmful speech raises ideas about the need to balance free speech against other claims, such as the right of others to protection from harm, that is a s.1 consideration.

Thus, the Court's position was to take a wide and expansive approach to defining the scope of s.2(b) and consequently making the shift to s.1 of the Charter more easily attainable. Using this approach, the Court held that s.2(b) did indeed include the freedom to promote hatred wilfully, and that competing considerations would be examined under s.1.

The Court appears to have changed the format of its s.2(b) analysis from its prior decisions. In the earlier case of Grier v. Alberta Association and Council of Management of Alberta Optometric Association ${ }^{13}$ the Alberta Court of Appeal found guidance in the words of Mr. Justice Dickson (as he then was) in R. v. Big $M$ Drug Mart $^{14}$ for defining s.2. In that case Mr. Justice Dickson stated: ${ }^{15}$

In my view this analysis is to be undertaken, and the purpose of the right or freedom in question is to be sought by reference to the character of the larger objects of the Charter itself, to the language chosen to articulate the specific right or freedom, to the historical origins of the concepts enshrined, and where applicable, to the meaning and purpose of the other specific rights and freedoms with which it is associated within the text to the Charter.

In Grier, Mr. Justice Kerans used the "character of the larger objects of the Charter" criterion to determine that s.2(b) would at least include "valued activities" in Canadian society. This analysis was again used by Justice Kerans in Edmonton Journal v. A.G. Alberta and A.G. Canada. ${ }^{16}$

11. Supra $\mathrm{n} .1$ at 268,19 C.C.C.

12. Supra n.1 at 13, 60 Alta. L.R.

13. [1987] 5 W.W.R. 539 at 542 (Alta. C.A.).

14. [1985] 1 S.C.R. 295, 3 W.W.R. 481, (1985) 37 Alta. L.R. (2d) 97, 18 D.L.R. (4th) 321 (S.C.C.).

15. Id. at 344 S.C.R.

16. [1987] 5 W.W.R. 385 (Alta. C.A.). 
In Keegstra, rather than beginning with the valued activity approach and then expanding s.2(b) protection to less valuable activities, Justice Kerans abandoned that analysis completely. This abandonment seems to have caused the most serious problem with the Court's s.2(b) analysis because, then left without a methodology, Justice Kerans entered an obscure analysis, juxtaposing on the one hand the wilful promotion of hatred, and on the other the spreading of calculated falsehoods, ultimately concluding - almost magically - that the former constitutes imprudent speech only. After acknowledging that not all speech was to be protected by s.2(b) and offering as an example of that the exclusion of publication of calculated falsehoods (as contemplated by s. 181 of the Criminal Code), His Lordship wrote: ${ }^{17}$

Mr. Fraser [counsel for the Crown] accepted that some false speech is protected (without the presence also of knowledge of harm) at least in the realm of public debate and exchange of political ideas. Indeed it would be a hollow right if, to assert it, we first had to demonstrate that what we had to say was correct. The toleration of at least some error is part of our tradition and has been justified on both practical and philosophical grounds.

The argument of Mr. Fraser is that a combination of untruth and "objective awareness" falls outside protection of s. 2 just like actual lies. Certainly, between the calculated falsehood on the one hand and innocent error on the other lies the middle ground of what one might call imprudent speech. By this I mean that the speaker is innocent of knowledge of the falsehood but is blameworthy in that he has not taken reasonable steps to discover if what he says is true or not. This seems to be the standard required by the law under review. Section $281.2(3)$ (c) provides that no person shall be convicted

if the statements were relevant to any subject of public interest, the discussion of which was for the public benefit, and if on reasonable grounds he believed them to be true . . .

The question, then, is whether imprudent speech is protected by the Charter.

It is submitted that the above conclusion is illusory because its premise is that wilful promotion of hatred depends on the use of false information and argument to achieve its goal. Such a view ignores the fact that a hatemonger may use either fact or fiction in his rhetoric and that the importance between the two only goes to whether the hatemonger will be afforded the defenses of truth (s.319(3)(a)) or reasonable belief that the statements were true (s.319(3)(c)). The distinction does not, however, provide a rational basis for determining that hate propaganda based on fictitious argument constitutes imprudent speech only. Thus, the Court erroneously reduced the level of culpability prohibited by s.319(2), thereby making it easier to include such activity under the protection of s.2(b).

Another problem in the Court's analysis of s.2(b) is its determination that s.27 of the Charter did not apply. The Court saw the alliance of ss. 15(1) and 27 as being a competing claim to s.2(b) and, therefore, left the issue to the office of s. 1 of the Charter. It is submitted, however, that $s .27$ has no competing claim with any section of the Charter because the section does not give rise to any particular right or freedom. Rather, it operates only to colour other sections of the Charter. Professor Gall states the relevant effect of s.27 as follows: ${ }^{18}$

. . . section 27 may serve first as an adjectival provision assisting in the interpretation of the meaning of specific s. 2 rights; and second, it may provide meaning and scope to the phrase 'free and democratic society' in $\mathbf{s . 1}$ in that section's application to $\mathbf{s . 2}$.

17. Supra n.2 at 183.

18. Gerald L. Gall, "Multiculturalism and the Fundamental Freedoms: Section 27 and Section 2" in Multiculturalism and the Charter: A Legal Perspective (1987) 29 at 37. 
If s. 27 cannot stand alone then neither should it be considered a "competing claim". The Alberta court, it is submitted, failed to apply the constitutive effect of s.27, notwithstanding the imperative language of the section to do so.

\section{B. R. v. ANDREWS}

In the Ontario Court of Appeal the majority determined that s.2(b) did not extend to the wilful promotion of hatred against an identifiable group. Mr. Justice Grange, speaking for himself and Mr. Justice Krever, stated:19

Freedom of speech or expression has never been absolute. It must, as this Court said in $R$. v. Zundel . . . necessarily have regard to the corresponding freedoms of other persons. It contemplates the existence of a social order in which other persons must not be denied similar rights."

His Lordship then went on to use the analysis in Zunde ${ }^{20}$ to define the scope of s.2(b). In Zundel the Court stated:21

When determining the limits of freedom of expression, a distinction must be drawn at the outset between "rights" and "freedoms". A "right" is defined positively as what one can do. A "freedom", on the other hand, is defined by determining first the area which is regulated. The freedom is then what existed in the unregulated area - a sphere of activity within which all acts are permissible. It is a residual area in which all acts are free of specific legal regulation and the individual is free to choose. The regulated area will include restrictions for purposes of decency and public order, and specifically with respect to the freedom of expression, prohibitions concerning criminal libel and sedition. It is what Rand J. described in Saumur v. City of Quebec and A.G. Que. as "the residue inside the periphery".

According to this analysis it falls to be determined whether s.319(2) of the Criminal Code properly forms part of the permissibly regulated area. If it does, then the action that it prohibits - wilful promotion of hatred - is not at all a freedom under s.2(b).

In deciding the issue, Justice Grange relied exclusively on the Cohen Committee Report. His Lordship quoted from the Report: ${ }^{22}$

In the Committee's view the 'hate' situation in Canada, although not alarming, clearly is serious enough to require action. It is far better for Canadians to come to grips with this problem now, before it attains unmanageable proportions, rather than deal with it at some future date in an atmosphere of urgency, of fear and perhaps even of crisis. The Canadian community has a duty, not merely the right, to protect itself from the corrosive effects of propaganda that tends to undermine the confidence that various groups in a multicultural society must have in each other.

. . . Canadians who are members of any identifiable group in Canada are entitled to carry on their lives as Canadians without being victimized by the deliberate, vicious promotion of hatred against them. In a democratic society, freedom of speech does not mean the right to villify [sic]. The number of organizations involved and the numbers of persons hurt is no test of the issue: the arithmetic of a free society will not be satisfied with over-simplified statistics demonstrating that few are casting stones and not many are receiving hurts. What matters is that incipient malevolence and violence, all of which are inherent in 'hate' activity, deserves national attention. However small the actors may be in number, the individuals and groups promoting hate in Canada constitute 'a clear and present danger' to the functioning of a democratic society. For in times of social stress such 'hate' could mushroom into a real and monstrous threat to our way of life.

He concluded:23

It may have taken a Great War to persuade some of us, but in my view, the Cohen Committee was right. The wilful promotion of hatred even more than spreading of false news is entirely antithetical to our very system of freedom.

19. Supra n.2 at 183 .

20. (1987) 58 O.R. (2d) 129, 56 C.R. (3d) 1, 31 C.C.C. (3d) 97, 35 D.L.R. (4th) 338 (Ont. C.A.).

21. Id. at 359-360 D.L.R.

22. Supra n.2 at 183. His Lordship was quoting from pages 24-25 of the Report.

23. Id. at 184 . 


\section{Justice Grange also included mention of s.27 of the Charter: $:^{24}$}

$\ldots$ if that section is to be of assistance in the interpretation of s.2(b), it can only reinforce my view that no protection is offered by s.2(b) to the conduct of the appellants.

Mr. Justice Cory, dissenting on the issue of s.2(b), argued that, because the wilful promotion of hatred does not fall within the category of wilful publication of false information (Zundel), nor would it be called speech antithetical to the freedom conferred by s.2(b) (Kopyto), it lies within the unregulated area of human activity and is, therefore, a freedom under s.2(b). He stated: ${ }^{25}$

Statements will often be made about identifiable groups within our society that will be contentious, irritating and annoying for they may not always be politely phrased. Yet they should receive the protection accorded by s.2(b).

...

The protection provided for freedom of expression must be wide enough to permit persons to set forward new and different ideas no matter how upsetting those ideas may be to identifiable groups.

He later added: ${ }^{26}$

Freedom of expression is of vital and fundamental importance to a free and democratic society and to its citizens. The courts should strive to uphold this precious freedom and should proceed cautiously in restraining it. Often it may be more appropriate to accept the freedom or right to make the statement and then determine if the statutory enactment restraining the challenged statement constitutes the reasonable limit referred to in $\mathrm{s.1}$ of the Charter which can be demonstrably justified in a free and democratic society.

The Alberta Court of Appeal would seem to agree, as shown by its comments in Grier. In that case Mr. Justice Kerans stated the following in regards to the Zundel analysis: ${ }^{27}$

The essence of the view just quoted is that the Charter offers constitutional protection only to human activity that falls in the "unregulated area". The "regulation" that the court has in mind is positive law, whether the common law or statutes. If this is so, the protection is an illusion: it creates a constitutional right to do whatever the law does not forbid. As I sought to say in Ref. re Pub. Service Employee Rel. Act. , the common law concept of liberty as the freedom to do that which is not forbidden is a negative or weak form of liberty, and the entire purpose of entrenchment is to give strength to the enumerated freedoms.

This criticism would be valid but for the fact that the Zundel Court used the phrase "permissibly regulated" and not simply "regulated". Thus, only "permissible regulation" will properly deny a freedom under the Charter.

The problem of the Zundel analysis, however, may not end at that point. If a court comes to determine that an area of human activity is not permissibly regulated by positive law (and, therefore, a "freedom" within the meaning of s.2), what analysis remains for the office of $s .1$ ? That is, for the question of determining whether or not regulation is permissible in a certain area of activity the analysis will inevitably involve the issue of reasonableness. The Zundel analysis begs the question: What is the difference between the finding of an impermissible regulation of an activity (under s.2) and the finding that a limitation of a Charter guarantee is not a reasonable one, demonstrably justifiable in a free and democratic society? The "residue inside the periphery" test appears to cloud the relationship between ss. 1 and 2 of the Charter.

24. Id.

25. Id. at 166 .

26. Id. at 173 .

27. Supra n.13 at 543 . 
In light of the recent Supreme Court of Canada cases of Ford v. Quebec (Attorney General ${ }^{28}$ and Irwin Toy v. Quebec (Attorney General) ${ }^{29}$ it now appears that the residue inside the periphery analysis has no application to s.2(b). In those two cases the Supreme Court, consistent with its previous dicta supporting a broad and inclusive approach to defining Charter rights and freedoms, structured a methodology for determining the scope of s.2(b). In Ford the Court stated: ${ }^{30}$

The issue in this appeal is not whether the guarantee of freedom of expression in s.2(b) of the Canadian Charter and s.3 of the Quebec Charter should be construed as extending to particular categories of expression, giving rise to difficult definitional problems, but whether there is any reason why the guarantee should not extend to a particular kind of expression . . . .

In Irwin Toy the Court determined that all human activity which attempts to convey a meaning is expressive and therefore within the guarantee of s.2(b). The only limitation stipulated was that s.2(b) did not protect violent expression or purely physical activity that does not convey a meaning. If the activity falls within s.2(b) protection, the Court said, it must further be determined whether the law, by governmental purpose or by effect, restricts an attempt to convey meaning. If the law does either, the freedom of expression has been breached, shifting the analysis to s.1.

This approach most closely compliments the view in Keegstra, avoiding a categorizational scheme and reserving the consideration of competing claims for the office of s.1. Such a balancing approach appears favourable as it minimizes the infusion of absolutist dogma which has historically been seen as denying constitutional protection to views and expressions outside the mainstream. ${ }^{31}$ It remains to be seen, however, whether such an inclusive approach to s.2(b) will have room for addressing the imperative language of s.27 of the Charter, as done by the Chambers judge in Keegstra.

In light of this recent Supreme Court authority, the wilful promotion of hatred against an identifiable group will be extended protection by s.2(b) because such expression is, first, an attempt to convey meaning; second, it is not violent activity (unless, of course, "violence" is interpreted to include psychological or physical harm, discrimination, or risk thereof); and third, it is clearly Parliament's purpose to limit this type of expression. If so, the discussion regarding s. 1 will take on greater significance.

\section{ANALYSIS OF SECTION 1}

\section{A. R. v. KEEGSTRA}

Mr. Justice Kerans analyzed s.319(2) by the procedure which he developed in Black v. Law Society of Alberta ${ }^{32}$ and subsequently applied in Edmonton Journal. His Lordship studied the validity of s.319(2) under the following headings: rationality, sufficiency, clarity, and finally proportionality, using the Oakes test. ${ }^{33}$

28. [1988] 2 S.C.R. 712 (S.C.C.).

29. Unreported, File No. 20074, April 27, 1989 (S.C.C.).

30. Supra $\mathrm{n} .28$ at 755.

31. This can be seen in early American jurisprudence involving the lst Amendment of the Bill of Rights. See Gitlow v. New York 268 U.S. (1925) and Chaplinsky v. New Hampshire 315 U.S. 568 (1942).

32. [1986] 3 W.W.R. 590, (A86) 44 Alta. L.R. 1, 27 D.L.R. (4th) 527 (Alta. C.A.).

33. [1986] 1 S.C.R. 103, (1986) 24 C.C.C. (3d) 321, 26 D.L.R. (4th) 200 (S.C.C.). 
In reviewing the rationality of s.319(2) Justice Kerans determined that the law met the need to protect the target group from damage to reputation and bodily harm. ${ }^{34}$ Other claims made by the Crown, such as the risk of civil disorder when victims react with anger, the risk of breakdown of traditional values from the "spread of the poison", and the Canadian commitment to the International Convention on the Elimination of All Forms of Racial Discrimination ${ }^{35}$ were rejected by His Lordship.

As protection from harm was accepted by the Court as the rationale for s.319(2), the next part of the analysis was to determine whether the social need was sufficient to displace the freedom of expression guarantee. Justice Kerans stated: ${ }^{36}$

The degree of possible injury, then, falls across a broad spectrum. At the one end lies the response of annoyance or frustration, at the other the sense of total alienation, of being a social outcast or a "second-class citizen". This distinction is the source of great difficulty in terms of a sufficient justification for limits on free speech. I read the Cohen Report as recognizing this distinction, and seeking to justify limits only on the more extreme forms of hatemongering. The difficulty is to draw a line.

I think that it can be drawn clearly at one point: does anybody actually hate me as a result of this abuse? If the hatemonger begins to gain an audience, if a significant number of people actually accept his message or if that is a serious risk, then I begin to suffer significant harm because my reputational integrity is at stake.

- .

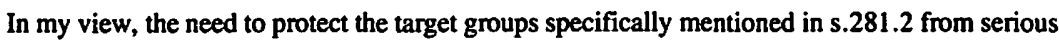
non-physical injury or reputational injury is a sufficient reason to limit imprudent speech. In other words, I accept that, sometimes, the harm is great enough to justify limits on the abuse. If I am right, the real issue is to gauge the proportionality of the intrusion, not to inveigh against all intrusions.

With regard to the issue of clarity, the Court held that any danger of s.319(2) being struck down by reason of vagueness could be rectified by proper judicial interpretation.

In addressing the issue of proportionality Justice Kerans used the three branch analysis of Oakes. His Lordship found that there was a rational connection between the objective of Parliament (protection of identifiable groups from serious harm) and the means chosen through s.319(2). ${ }^{37}$ In the analysis of the second and third branches of the proportionality test, Justice Kerans determined that s.319(2) failed as it was overly broad and its infringement of s.2(b) was disproportionate to its objective. He stated: $:^{38}$

Section 281.2 requires only the promotion of hatred, it does not require successful promotion. It does not require, for guilt, the slightest degree of communal acceptance of the hatemonger's message notwithstanding that, as I have said, the key to serious harm is precisely that. Nor does it require any serious risk of that event. An accused can be convicted even though nobody believes him, or is likely to believe him.

All this arose because the Cohen Committee suggested, and Parliament accepted, civil libel as a model for this law. In a libel case, injury need not be proven, it is assumed. . . . In the context of civil law, a presumption of damage to reputation simplifies proceedings, and a review of actual harm arises on assessment of damages. The transfer of that approach to the criminal law produces the impossible result that an accused cannot escape condemnation even by proving that he in fact caused injury to no person and no reputation.

In my opinion, this rule is overly broad.

34. Supra n.1 at 17, 60 Alta. L.R.

35. (1963), Yearbook of the United Nations 330, 3 I.L.M. 164, 58 A.J.I.L. 1081, 660 U.N.T.S. 195.

36. Supra n.1 at 20-21, 60 Alta. L.R.

37. Id. at 25-26.

38. Id. at 26-27. 


\section{Justice Kerans concluded: ${ }^{39}$}

It might be said that it would be impossible for the Crown to prove that the promotion has succeeded. I do not accept that. If the accused offers any real threat to the target groups the Crown should be able to prove it.

The Ontario Court of Appeal in Andrews was critical of Justice Kerans' approach. Justice Cory stated: ${ }^{40}$

Much of the Criminal Code is aimed at crime where no harm has been occasioned. For example, the very serious crime of attempted murder may be established when no harm has been suffered by the intended victim. By some fortuitous circumstances the aimed bullet missed its mark, the pointed knife was deflected, the poison cup was spilled on the ground. Although there was no damage or injury occasioned, the serious crime was nonetheless committed. As well, a conspiracy to import a large amount of heroin constitutes a crime. This is so even if the conspiracy is not brought to fruition and the heroin was never imported. Nonetheless the crime was committed, although no actual harm or even risk of harm was demonstrated. A driver with a blood alcohol count of over 80 is guilty of an offence although it has not been demonstrated that the particular accused has occasioned any danger to a victim or that his driving at the moment of apprehension constituted a danger in itself. Rather, the very basis for creating the offence of driving over 80 $\mathrm{mg}$ is founded upon empirical data as to the danger that people driving a motor vehicle with such a blood alcohol count constitute to members of the public.

He then added:41

The empirical data derived from the history of the Third Reich and the studies of the Cohen Committee are, I think, entitled to the same weight. They establish not only the risk of harm occasioned to identifiable groups by the promotion of hatred but the actual harm caused. They establish the need to restrain its promotion and they fully justify the application of s.1 of the Charrer to its provisions.

What is the policy decision behind the prohibition of attempted murder or driving while impaired? In the case of attempted murder, we as a society find the act of murder so heinous and such an affront to humanity that its mere attempt must be deterred and punished. For driving while impaired, we know the likelihood of harm to persons and property rises dramatically when a person drives impaired; that is, we expect harm. Therefore, Parliament wishes to prevent harm by criminalizing impaired driving. Hate mongering is not any different. The Cohen Committee has told Parliament that we can expect harm when a person attempts to disseminate hatred towards an identifiable group. We do not have to wait for a clear manifestation of harm to prove what is already known.

The harms caused by hate propaganda are sometimes difficult to detect immediately. Of course we can point to examples such as the Holocaust in Nazi Germany and violent acts committed by the Ku Klux Klan on Blacks in the United States, but harm also takes less obvious forms. For example, would it be realistic to expect the Crown to prove in a given case that Ms. A. was denied an employment opportunity with a particular company because the personnel officer, Mr. B., had recently heard and believed a speech promoting hatred toward an identifiable group of which Ms. A. was a member? It is even more difficult to prove the subtleties of hate dissemination through indoctrination. For example, if a hatemonger is a charismatic personality in a community, he may very well have the tools and skills required to persuade the listener to adopt prejudicial attitudes. The only way the Crown could prove the listener has been affected is by calling him to the witness stand and asking: "Do you now hate this particular minority group by reason of what the accused told you?" The indoctrinated listener, however, may not really know the answer.

39. Id. at 28.

40. Supra $\mathrm{n} .2$ at 180.

41. Id. 
As well, it may be very difficult, if not impossible, to obtain accurate data to prove or disprove the effects of hatemongering. Unlike measuring the physiological effects of alcohol on the human body, hate propaganda deals with persuasion, nurturance, and indoctrination. Because the effects cannot be measured by the hard sciences, there may always be some doubt as to the accuracy of conclusions arrived at in sociological and psychological studies. For instance, it would indeed be difficult to find human subjects for clinical experiments who have not already been tainted by past experience and bias.

There has been, however, historical data that has shown a link between hate propaganda and potential harm to targeted groups. Such data was the subject of study in the Cohen Committee Report. As well, others have theorized on the link. Professor Kretzmer writes: ${ }^{42}$

From the general proposition that speech may influence ideas, beliefs and attitudes, it follows that racist speech may induce non-racists to adopt racist beliefs, attitudes and ideas that may reinforce such beliefs, attitudes, or ideas among racists. This means that racist speech may increase the incidence of racial prejudice and discrimination in society. As we have posited that racial prejudice and discrimination are social evils which offend fundamental principles of democracy, an increase in their incidence must be regarded as harm.

He later adds: $:^{43}$

Support for the theoretical connection between racist speech and racist action made by social psychologists and sociologists is often drawn from the experience of societies which have given racist speech free rein. The main example cited is the case of Naziism in Germany. I do not suggest that allowing racist speech necessarily leads to the extremes of Nazi Germany. Speech on its own does not necessarily lead to action. However, there can be little doubt that speech plays a central role in creating the system of beliefs, attitudes, and motivations in people who hold those attitudes and subscribe to those beliefs. Thus, while Hitler would probably never have come to power had there not been a breakdown in the social, political, and economic system in Germany, this same environment could not itself have bred the anti-Semitic regime. For this, it was essential that pre-existing ideas, attitudes, and beliefs be socially prevalent, and that Hitler have the freedom to espouse publically and disseminate his anti-Semitic propaganda which fed on those ideas, attitudes and beliefs.

A more specific analysis of the potential harms of prejudice has been outlined by social-psychologist Gordon Allport. ${ }^{44}$ According to Professor Allport, there are five progressive stages of racial prejudice: antilocution (expression of prejudicial attitudes), avoidance, discrimination, physical attack, and extermination. ${ }^{45}$

According to this theory, attainment of each progressive level is dependent on activity at the preceding level. He writes: ${ }^{46}$

It was Hitler's antilocution that led Germans to avoid their Jewish neighbours and erstwhile friends. This preparation made it easier to enact the Nuremberg laws of discrimination which, in turn, made the subsequent buming of synagogues and street attacks upon Jews seem natural. The final step in the macabre progression was the ovens at Auschwitz.

Another concern that should be addressed is that of the Alberta court ignoring the relevance of Canada's international treaty commitments. The International Convention on the Elimination of All Forms of Racial Discrimination, a treaty to which Canada is a party, states in Article 4(a) that the signatories to the treaty ". . . shall declare an offence punishable by law all dissemination of ideas on racial superiority

42. David Kretzmer, "Freedom of Speech on Racism" (1987) 8 Cardozo L. Rev. 445 at 462.

43. Id. at $463-464$.

44. Gordon W. Allpon, The Nature of Prejudice (1954).

45. Id. at 14-15.

46. Id. 
and hatred . . .". Justice Kerans alluded to the fact that such an undertaking may be contrary to s.2(b) of the Charter and then stated:47

It may be that an international commitment in contradiction of a Charter term can be validated under s.1, but we do not need to address that difficult issue in this case because this law [s.319(2)] goes beyond the condemnation of ideas based on racial hatred. [Emphasis added]

This is hardly an attempt to catch the spirit of the Convention. Moreover, if the Court had been looking for more specific language it should have observed that Canada is also a party to the International Covenant on Civil and Political Rights. ${ }^{48}$ Article 20(2) of the Covenant reads:

Any advocacy of national, racial or religious hatred that constitutes incitement to discrimination, hostility or violence shall be prohibited by law.

It may be that Canadian Charter law will conflict with some international treaty commitments, but there is little reason to find such a conflict here. Not only is discrimination on the basis of race, religion or colour, or the advocacy of it, offensive to human dignity and rejected by other egalitarian democracies, it is fundamentally antithetical to the Canadian ideal of a "free and democratic society".

\section{B. R. v. ANDREWS}

As already noted, the majority of the Ontario court found no breach of s.2(b) of the Charter by the criminal statute. It stated that if it was wrong on the issue, however, it would concur with Justice Cory's analysis of s.1.

Justice Cory began his analysis of $\mathrm{s.} 1$ by examining its possible meaning. His Lordship discussed both the application of s.27 of the Charter to $s .1$ and the relevance of the International Convention on the Elimination of All Forms of Racial Discrimination. With respect to 5.27 Justice Cory determined that it went directly to the defining of the Canadian version of a "free and democratic society". He noted: 49

It should be observed that the impugned section is aimed at restricting public statements which wilfully promote hatred against a group which can be identified by its colour, race, religion or ethnic origin. Without even considering the special defences which are provided by s.281.2(3), it can be seen that ss.281.2(2) does not in any way restrict criticism, including intemperate criticism, of public institutions. Rather, it is designed to prevent the destruction of our multi-cultural society.

The fact that Canada was party to the Convention seemed much more important to Justice Cory than it did to Justice Kerans. Justice Cory stated: ${ }^{\text {so }}$

That commitment by Canada as well as other countries would seem to indicate that s.281.2 was demonstrably justified in free and democratic societies. The Convention is designed to eradicate the promotion of hatred against identifiable groups, an evil which has been recognized by the intemational community.

In determining the underlying values and principles of the Charter, Justice Cory also cited the dicta of Chief Justice Dickson in Oakes. There the Chief Justice stated: ${ }^{5 l}$

The court must be guided by the values and principles essential to a free and democratic society which I believe embody, to name but a few, respect for the inherent dignity of the human person,

47. Supra n.1 at 18-19, 60 Alta. L.R.

48. (1966), 21 U.N.G.A. O.R. Supp. 16 U.N. Doc A/6316 at 52.

49. Supra n.2 at 174.

50. Id. at 177.

51. Supra n.33 at 136 S.C.R. 
commitment to social justice and equality, accommodation of a wide variety of beliefs, respect for cultural and group identity, and faith in social and political institutions which enhance the participation of individuals and groups in society. The underlying values and principles of a free and democratic society are the genesis of the rights and freedoms guaranteed by the Charter and the ultimate standard against which a limit on a right or freedom must be shown, despite its effect, to be reasonable and demonstrably justified.

In holding that s.319(2) answers a pressing and substantial concern to a free and democratic society, Justice Cory noted: ${ }^{52}$

Section $281.2(2)$ seeks to protect identifiable groups in a multicultural society from publicly made statements which wilfully promote hatred against them. It has been seen that to promote hatred against an identifiable group is contrary to and is the antithesis of the underlying values and principles of a democratic society. The object of s.281.2 to protect identifiable groups from the wilful promotion of hatred against them constitutes a measure of sufficient importance to warrant overriding the constitutionally protected freedom of expression. The objective clearly relates to a concem which is pressing and substantial. [Emphasis added]

Aside from the overly brief application of the Oakes test, the author finds two aspects of the analysis objectionable. First, Justice Cory did not adequately deal with the Keegstra Court's concern that s.319(2) was overly broad. Justice Cory stated: ${ }^{53}$

It is narrowly drawn. It should not be struck down simply because one can imagine a rare and occasional application of its provisions that goes beyond constitutional bounds.

Unless His Lordship was referring to the developing remedy of the constitutional exemption, such a conclusion is dangerous. It would also contradict Oakes. When a law is " beyond constitutional bounds", even in rare circumstances, it is unconstitutional. If the criminal sanction is too broad, it should fail the proportionality test. As well, even though the fiat requirement of s.319(6) provides some protection for imprudent speakers, it is still not enough to validate a law that is unconstitutional by reason of its lack of proportionality with its objective. Such a conclusion by His Lordship makes it unclear whether he was truly convinced of the statute's constitutional validity.

The second troublesome aspect of Justice Cory's analysis of s. 1 is his determination that the pressing and substantial objective of s.319(2) is simply to stop the wilful promotion of hatred against identifiable groups. Rather, it is submitted, the prohibition is a means to attaining the objective of protection of targeted groups who are most likely to suffer harm from hate propaganda. If, however, the objective were simply to prohibit expression, on grounds of its content and for no further purpose, it would result in a categorization analysis within s.1, thus effecting a "carving-out" from Charter protection of hate propaganda notwithstanding that such expression has already been extended the guarantee of s.2(b). Such an approach would leave little room for balancing competing claims or insuring a proper tailoring of means to ends under the rest of the s. 1 analysis. Furthermore, it would indeed be difficult to accept censorship, for its own sake, as a pressing and substantial concern in a free and democratic society.

The Supreme Court of Canada's decision in Irwin Toy may create a significant change in the analysis of s.319(2) under s. 1. In that case, Chief Justice Dickson said of the minimal impairment analysis of the Oakes test: ${ }^{54}$

52. Supra $\mathrm{n} .2$ at 178.

53. Id. at 181 .

54. Supra $\mathrm{n} .29$ at $71-72$ S.C.J. 


\begin{abstract}
... in matching means to ends and asking whether rights or freedoms are impaired as little as possible, a legislature mediating between the claims of competing groups will be forced to strike a balance without the benefit of absolute certainty concerning how that balance is best struck. Vulnerable groups will claim the need for protection by the government whereas other groups and individuals will assert that the government should not intrude . . . .

When striking a balance between the claims of competing groups, the choice of means, like the choice of ends, frequently will require an assessment of conflicting scientific evidence and differing justified demands on scarce resources. Democratic institutions are meant to let us all share in the responsibility for these difficult choices. Thus, as courts review the results of the legislature's deliberations, particularly with respect to the protection of vulnerable groups, they must be mindful of the legislature's representative function . . . .

In other cases, however, rather than mediating between different groups the government is best characterized as the singular antagonist of the individual whose right has been infringed. For example, in justifying an infringement of legal rights enshrined in ss.7 to 14 of the Charter, the state, on behalf of the whole community, typically will assert its responsibility for prosecuting crime whereas the individual will assert the paramountcy of principles of fundamental justice. There might not be any further competing claims among different groups. In such circumstances, and indeed whenever the government's purpose relates to maintaining the authority and impartiality of the judicial system, the courts can assess with some certainty whether the "least drastic means" for achieving the purpose have been chosen . . . .
\end{abstract}

Therefore, it must now be asked: Does s.319(2) exist, in substance, as a law of mediation between competing claims within the polity or rather as a law singularly antagonistic to the individual? If it is the former the Court will only determine "whether the legislature had a reasonable basis, on the evidence tendered", for concluding that the means chosen in s.319(2) impaired the freedom of expression as little as possible given the pressing and substantial objective. If the law is singularly antagonistic, however, pitting the interests of the community in general against the individual, then the Crown must prove with greater certainty that the means chosen were the least drastic means available.

It is the author's opinion that s.319(2) is a mediative provision. This is shown by the purpose of the law as described by the Cohen Committee itself. It stated: ${ }^{s 5}$

The prevailing view in Canada is that freedom of expression is a qualified right, representing the balance that must be struck between the social interest in the full and frank discussion necessary to a free society on the one hand, and the social interests in public order and individual group reputation on the other hand.

We have concluded that this new offence is desirable even though we realize that it goes beyond what has hitherto been thought by many to be the proper sphere of criminal law, for such group defamation requires no breach of the peace and no showing of likely injury to the reputation of any person. In effect, it sets out as a solemn public judgment that the holding up of identifiable groups to hatred or contempt is inherently likely to expose them to loss of respect among their fellow men. We are convinced that the evidence justifies this policy judgment and that in our present stage of social development the law must begin to take account of the subtler sources of civil discord.

The fact that there is a community interest in curbing hate propaganda and its effects should not be enough to characterize the law as singularly antagonistic to the individual. All laws are made with an expectation of some general public benefit, even when one remedies a specific and narrow circumstance which involves the competing interests of various groups.

In light of the Alberta Court of Appeal in Keegstra deciding that s.319(2) failed the second and third branches of the proportionality test, Irwin Toy is significant as it may prove to ease the burden placed on the Crown in meeting, at least, the second branch. If so, and the Crown succeeds, the analysis would come down to 


\section{CONCLUSION}

The Keegstra and Andrews decisions have left the issue of s.319(2)'s constitutionality still unresolved in Canada. The majority of the Ontario Court of Appeal determined that the wilful promotion of hatred against an identifiable group is harmful and should, therefore, not be extended protection by s.2(b) of the Charter. The Alberta Court of Appeal agreed with the policy of having anti-hate legislation in the Criminal Code but found that s.319(2) was too broad because an accused may be convicted notwithstanding that nobody listened to, or accepted his views.

The Supreme Court of Canada's guidance regarding the scope of s.2(b) now makes it appear that the protection of s.2(b) will be extended to the wilful promotion of hatred against an identifiable group. If so, the $s .1$ analysis will be resolved on the basis of the question of harm. The Alberta Court did not accept that real harm should be presumed from the accused's actions; rather, the law should only catch those who have effected their hateful views onto a listener. As argued by this author, harm, in the form of avoidance, discrimination or violence, as well as psychological harm, may indeed result from hatemongering notwithstanding the difficulty in proving its causal connection to a particular speaker. That is, harm can be expected. This view was accepted by the Ontario Court as it compared hatemongering with other crimes such as impaired driving; in both, despite the fact that no harm may occur in a given situation, the risk of it justifies criminal sanction.

It may be said that we cannot deny Charter protection to expression that is unpopular or promotes a view of the policy which is different from the mainstream because firstly, such would undermine the teaching of tolerance manifested by the Charter, and secondly, such expression is tantamount to political speech. In response, it can only be said that we should indeed limit those forms of expression that create a risk of harm to members of our society. Furthermore, it is ironic, on the one hand, to call defamation of one person a tort, and on the other hand call defamation of an entire racial, religious, or ethnic group political speech and thus protected. The character of the speech should not be seen to have changed simply because the speaker had increased the number within his target. 